\title{
Full-length Fas-associated Death Domain Protein Interacts with Short Form of Cellular FLICE Inhibitory Protein
}

\author{
Mi Suk Jeong and Se Bok Jang \\ Korea Nanobiotechnology Center, Pusan National University, Busan 609-735, Korea. *E-mail: sbjang@ipntsan.ac.kr \\ Received November 9, 2005
}

\begin{abstract}
Fas-associated death domain protein $(\mathrm{F} \Lambda \mathrm{DD})$ recruits and activates procaspase- 8 through interactions between the death effector domains of these two proteins. Cellular FLICE-inhibitory protein (c-FLIP) was identified as a molecule with sequence homology to caspase-8. It has been postulated that c-FLIP prevents formation of the competent death-inducing signaling complex in a ligand-dependent manner, through its interaction with FADD and/or caspase-8. Ilowever, the interaction of F $\triangle D D$ and $c-F L I P$ (short form) in apoptosis signaling has been controversially discussed. We show the purification and the characterization of human full-length FNDD and c-FLIPs expressed in Escherichia coli. The puritied FADD and c-FLIPs are shown as homogeneity, respectively, in SDS-P $\Lambda \mathrm{GE}$ analysis and light-scattering measurements. The folding properties of the $\alpha$-helical structure of F $\triangle D D$ and the super-secondary structure of c-FLIPs proteins were characterized by circular dichroism spectroscopy. Furthermore, we report here a series of biochemical and biophysical data for F $\mathrm{DDD}$ c-FLIPs binding in vitro. The binding of both $\mathrm{F} \Lambda \mathrm{DD}$ and $\mathrm{c}-\mathrm{FL} \mathrm{P}_{\mathrm{s}}$ proteins was detected by BI $\Lambda$ core biosensor, fluorescence measurement, and size-exclusion column (SEC).
\end{abstract}

Key Words : Overexpression, Purification, Full-length FADD, c-FLIPs (short form), Interaction

\section{Introduction}

Apoptosis, or programmed cell death, is critical for tissue homeostasis in multicellular organisms. Many diseases are associated with either too much or too little apoptosis, such as AIDS, cancer, and autoimmunity.' Apoptosis is initiated by a variety of stimuli, including growth factor withdrawal, UV or $\gamma$-irradiation, chemotherapeutic drugs, and death receptor signals. The death receptors contain an intracellular death domain (DD), which is essential for transduction of the apoptotic signal. Six subfamily members of death receptors are known so far, TNFR1 (also called CD120a), CD95 (APO-1/Fas), DR3 (APO-3, LARD, TRAMP, and WSL1), TRAIL-R1 (APO-2 and DR4), TRAIL-R2 (DR5, KILLER, and TRICK2), and DR6. ${ }^{2}$ Death receptors are activated by their natural ligands, which have coevolved as a death ligand family, called the tumor necrosis factor (TNF) family.

Fas-associated death domain protein (FADD) is an adaptor molecule that bridges the interactions between membrane death receptors and initiator caspases. Caspases are a family of aspartate-specific cysteine proteases that are necessary for execution of apoptosis. The clustering of Fas receptors, FADD, and procaspase- 8 , termed death-inducing signaling complex (DISC), is essential for Fas-mediated apoptosis and caspase-8 activation. ${ }^{3.4}$ In death-inducing signaling complex formation, FADD mediates signals from Fas receptors to procaspase- 8 with its C-terminal death domain (DD) and Nterminal death-effector domain (DED). FADD also participates in signaling other members of the tumor necrosis factor receptor (TNFR) family.

TNF-related apoptosis-inducing ligand (TRAIL) is a type II membrane protein that is processed proteolytically at the cell surface to form a soluble ligand. ${ }^{5-8}$ Due to the tumor selectivity of FADD-induced apoptosis and its ubiquitous expression, it has been postulated that the apoptosis pathway induced by TRAIL is tightly regulated by several mechanisms to prevent spontaneous cell death. One such mechanism involves the cellular inhibitor of apoptosis, cellular FLIP (cFLIP), which is also known as I-FLICE, FLAME, CASPER, or $\mathrm{CASH}^{9-15}$ c-FLIP molecules have several altemative splicing variants at the transcriptional level, but at the protein level, two isoforms of c-FLIP, the long form (cFLIP $\left._{L}, 55 \mathrm{kDa}\right)$ and the short form (c-FLIPS, $28 \mathrm{kDa}$ ), exist. ${ }^{11.16} c-F L I P L$ contains an additional caspase-like domain at its C-terminal part that is deficient in c-FLIPS. cFLIP is a human homolog of viral FLICE-inhibitory proteins (v-FLIPs), which are components of $\gamma$-herpesvirus and have anti-apoptotic activity. ${ }^{9} \mathrm{~A}$ short form of c-FLIP structurally resembles v-FLIP. ${ }^{11}$ Conflicting data exist about the direct interaction of FADD and c-FLIP in apoptosis signaling. 11.12 .14 .15

Herein, we show the methods of efficient overexpression and purification that generate homogeneous full-length FADD and c-FLIPs proteins. Furthermore, we report a series of biochemical and biophysical data for FADD-c-FLIPS binding. Until now, there have been no reports of full-length FADD and c-FLIPS structures. This study could be preliminary studies for the structural bases and identification of the apoptotic signaling pathways of FADD and c-FLIPs proteins.

\section{Materials and Methods}

Subcloning, Expression, and Purification. In the present study, full-length human FADD (1-208 amino-acids) and c- 
FLIPS (short form, 1-221 amino-acids) were subcloned into non his-tagged vectors, $\mathrm{pQE}-30$ and $\mathrm{pET}-21 \mathrm{~b}$, respectively. FADD and c-FLIPs were expressed in Escherichia coli BL21(DE3) strains. Cells were initially grown in $5 \mathrm{~mL}$ of LB-ampicillin $(50 \mu \mathrm{g} / \mathrm{mL})$ overnight and maintained at 37 ${ }^{\circ} \mathrm{C}$. Inoculars were added to $2 \mathrm{~L}$ of $\mathrm{LB}$-ampicillin. The large cultures were immediately moved to an incubator at $37^{\circ} \mathrm{C}$. When the culture reached an $A+00$ of $0.5-0.7$, isopropyl $\beta-\mathrm{D}$ thiogalactopyranoside (IPTG) was added at a final concentration of $1 \mathrm{mM}$ to induce FADD as well as c-FLIPs. After 4$6 \mathrm{hrs}$, the cells were harvested and stored frozen at $-70^{\circ} \mathrm{C}$. FADD and c-FLIPS bacterial lysates were prepared by sonication in buffer $(50 \mathrm{mM}$ Tris- $\mathrm{HCl}[\mathrm{pH} 8.0], 200 \mathrm{mM}$ $\mathrm{NaCl}, 5 \%$ Glycerol, and $1 \mathrm{mM} \mathrm{DTT}$ ). Up to $20 \%$ ammonium sulfate for FADD was added to the soluble fraction of the cell extract. The precipitated FADD cell pellets were resuspended two times in buffer $\mathrm{A}(30 \mathrm{mM}$ ammonium acetate $[\mathrm{pH} 4.0], 300 \mathrm{mM} \mathrm{NaCl}, 0.1 \%$ Triton $\mathrm{X}-100$, and 1 $\mathrm{mM}$ DTT). The $\mathrm{pH}$ in the protein solution was changed to protect the aggregation by $30 \mathrm{mM}$ sodium citrate $(\mathrm{pH} 5.0-$ 5.5). The supernatant for the FADD was used in purification, but $c$-FLIPS was used as the pellet in purification. The inclusion body for $c$-FLIPs was resuspended more than five times in buffer A. All of the purification methods required a superdex 75 column (Amersham-Biosciences). The fulllength FADD and c-FLIPs protein solutions were concentrated to $3-5 \mathrm{mg} / \mathrm{mL}$ using a Vivaspin 20 (Satorius).

Refolding. To obtain more soluble and stable proteins of FADD and c-FLIPs for crystallization, a refolding process was performed. The full-length FADD and c-FLIPS genes were subcloned into expression vectors, his-tagged $\mathrm{pET} 15 \mathrm{~b}$ and $\mathrm{pET}-21 \mathrm{~b}$, respectively. The constructs were transformed into the expression host Escherichia coli BL21(DE3)RIL strains. The cells were disrupted in buffer B $(50 \mathrm{mM}$ Tris$\mathrm{HCl}[\mathrm{pH} 8.0], 200 \mathrm{mM} \mathrm{NaCl}$, and $1 \mathrm{mM}$ DTT) by sonication on ice at a high setting for five cycles of $20 \mathrm{~s}$ with a $5 \mathrm{~min}$ gap between each cycle, and then centrifuged at $14,500 \mathrm{rpm}$ for $15 \mathrm{~min}$ at $4{ }^{\circ} \mathrm{C}$. The inclusion bodies of the FADD and $\mathrm{c}$ FLIPS were resuspended under protein denaturing conditions in buffer $\mathrm{B}$ containing $6 \mathrm{M}$ urea. The resuspended cells were then centrifuged at $14,500 \mathrm{rpm}$ for $45 \mathrm{~min}$ at $4{ }^{\circ} \mathrm{C}$ in a refrigerated high speed centrifuge. The supernatant was collected and loaded onto a column containing $7 \mathrm{ml}$ preequilibrated Ni-NTA resin. The loaded protein was refolded by gradient against refolding buffer $B$. The resin was washed with buffer $B$ containing $20 \mathrm{mM}$ imidazole and then eluted with buffer B containing $200 \mathrm{mM}$ imidazole. The eluted fractions were dialyzed against buffer $B$ to remove the imidazole. The FADD and c-FLIPs proteins were purified as (His) 6 -tagged fusion proteins. All purifications required the nickel-nitriltriacetic acid (Ni-NTA) column (Qiagen), the resource $\mathrm{Q}$ anion exchange column (Amersham Biosciences), and a Superdex 75 column (Amersham-Biosciences). The purity of purified FADD and c-FLIPS was determined by sodium dodecyl sulfate-polyacrylamide gel electrophoresis (SDS-PAGE) with $4 \%(\mathrm{w} / \mathrm{v})$ stacking and $15 \%(\mathrm{w} / \mathrm{v})$ resolving gels. The protein solutions were concentrated to $6-10$ $\mathrm{mg} / \mathrm{ml}$ using a Vivaspin 20 (Satorius).

The purified FADD and $c$-FLIPS were mixed in $1: 1$ molar ratio. After incubation for $12 \mathrm{hrs}$ at $4{ }^{\circ} \mathrm{C}$, the mixture was loaded on Superdex 200 HR 10/30 size-exclusion column (SEC) (Amersham Pharmacia Biotech). The fractions containing the FADD-c-FLIPs complex were collected and boiled at $90^{\circ} \mathrm{C}$ for $10 \mathrm{~min}$ to elute the proteins followed by loading on SDS-PAGE. The native gel electrophoresis $(12.5 \%)$ was carried out at $4{ }^{\circ} \mathrm{C}$ using $1 \times$ gel buffer.

Circular Dichroism (CD) spectroscopy. Data were collected on a JASCO J-715 spectropolarimeter equipped with a thermoelectric temperature controller. CD spectra were recorded with protein samples $(5-10 \mathrm{uM})$ in a $20 \mathrm{mM}$ phosphate buffer [pH 5.0] at $25^{\circ} \mathrm{C}$ over the range of $200-260$ $\mathrm{nm}$ in a nitrogen atmosphere. Each spectrum was the accumulation of three scans corrected by subtracting signals from the buffer control. The resulting spectrum was smoothed and corrected for mean residue weight concentration and cell pathlength using JASCO data analysis software.

Dynamic Light Scattering (DLS). All of the samples were degassed and dust-free. The dynamic light-scattering spectra of the FADD and c-FLIPs were obtained to identify the distributions of species of differing molecular masses, degree of aggregation, shape, and branching (SEC-mode). Light-scattering spectra were recorded with protein samples $(0.1-0.2 \mathrm{uM})$. The molecular weight range was measured from $\sim 10^{3}$ to $\sim 10^{9}$ Daltons, and the molecular size range was measured from 10 to $500 \mathrm{~nm}$.

BIAcore Biosensor Analysis. Measurements of the apparent dissociation constants $\left(K_{\mathrm{D}}\right)$ between FADD and cFLIPs were carried out using a BIAcore 2000 biosensor (Biosensor, Sweden). FADD (30 ug/ $/ \mathrm{ml}$ in $10 \mathrm{mM}$ MES [pH $6.0]$ ) was covalently bound to the carboxylated dextran matrix at a concentration corresponding to $-1,200$ response units (RU) by an amine coupling method, as suggested by the manufacturer. A flow path involving two cells was employed to simultaneously measure the kinetic parameters from one flow cell containing the FADD-immobilized senor chip to the other flow cell containing an underivatized chip. For kinetic measurements at room temperature, c-FLIPS samples, ranging from 50 to $500 \mathrm{nM}$, were prepared by dilution with an $\mathrm{HBS}$ buffer $(150 \mathrm{mM} \mathrm{NaCl}, 3 \mathrm{mM}$ EDTA, $0.005 \%$ polysorbate, and $10 \mathrm{mM}$ HEPES [pH 7.4]). Each sample was injected with $150 \mathrm{uL}$ of $\mathrm{c}$-FLIPSs solution into the flow cells (association phase) at $30 \mathrm{uL} / \mathrm{min}$. Between cycles, the immobilized ligand was regenerated by injecting $30 \mathrm{uL}$ of $100 \mathrm{mM}$ glycine hydrochloride $[\mathrm{pH} 2.0]$ at $10 \mathrm{uL} / \mathrm{min}$.

Fluorescence Spectroscopy. Fluorescence emission spectra were obtained on a Quantamaster spectrofluorimeter model C-61SE (Photon Technology International) using $1 \mathrm{~cm}$ path length cuvettes with excitation and emission slit widths of 5 $\mathrm{nm}$. The fluorescence emission spectra of the FADD and cFLIPS were obtained to identify characteristic structures, namely double bonds and aromatic groups, in molecules of varying complexities. The emission intensity was measured from 280 to $400 \mathrm{~nm}$ with an excitation at $295 \mathrm{~nm}$. All of the spectra were taken at a protein concentration of $50 \mathrm{ug} / \mathrm{mL}$ at 
24 "C. Ten spectra of each protein sample were aceumulated, averaged, and subjected to baseline correction by subtracting the bufler spectrum.

\section{Results and Discussion}

The F/ГГ) was expressed mainly as a soluble form at 37 "C in the $E$. coll BL2I(DF:3) host using the pQF,-30 vector (Fig. la). The supernatant for the FADD was used in purification, but the c-FILIPs using the pET-2 I b vector was used as a pellet in purification (Fig. Ib). The inclusion body for the c-FLIPs was resuspended more than live times by the resuspension bufler $\wedge(30 \mathrm{mM}$ ammonium acetate [pI 4.0 ], $300 \mathrm{mM} \mathrm{NaCl}, 0.1 \%$ Triton $X-100$, and $1 \mathrm{mM}$ [DTT). To prevent aggregation the pll of the protein solution was raised to the pH 5.0-5.5 using $30 \mathrm{mM}$ sodium citrate. The recombinant FADD and e-FLIPs were purilied in the correctly folded state as indicated by several lines of evidence. To obtain more soluble and stable proteins of FADD and c-FLIPS, the refolding process was performed. The purified $F \triangle D D$ and $c-F L I P$ s each showed a homogeneous single band in an SDS-PAGI analysis (Figs. $I c$ and $d$ ). Protein expression as inclusion bodies provides us with a significant amount of pure protein for further biophysical and struetural studies. In these studies, the separated fractions of FADD protein, after using a superdex-75 column, were shown in two types of peaks in the eluted fractions and in two bands in the SDS-PAGE analysis (Fig. le). Only the first peak was identified as the homogeneity in the native gels and the second peak was presumed to the aggregales of higher mass. On the other hand, c-FLIPS protein was eluted as a sharp single peak from a superdex -75 column that was employed as a final purification step, which is an indication of structural homogeneity. We have successively obtained soluble proteins to final concentrations of $8 \mathrm{mg} / \mathrm{ml}$ for ГАГГГ) and $6 \mathrm{mg} / \mathrm{mL}$ for $\mathrm{c}-\mathrm{FLIP}_{\mathrm{S}}$, using a guantification $\mathrm{kit}$ with bovine serum (Figs. Ic and d).

The folding properties of both the FADD and c-FLIPs proteins were characterized by CD spectroseopy and lightscatlering measurements (Figs. 2 and 3). To determine the nature of the secondary structural elements of FADD and cFL.IPs, far-UV CD-spectra were recorded and analysed. The secondary structural element and conformational property of FADD were somewhat different from those of c-FLIPS. The CD spectrum of the purified FADJ) exhibited two negative maxima at 208 and $222 \mathrm{~nm}$, and that of the purilied c-FLIPS (a)

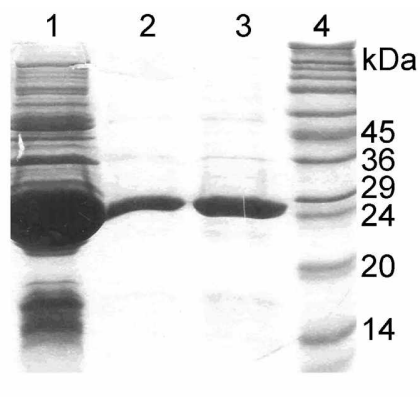

(b)

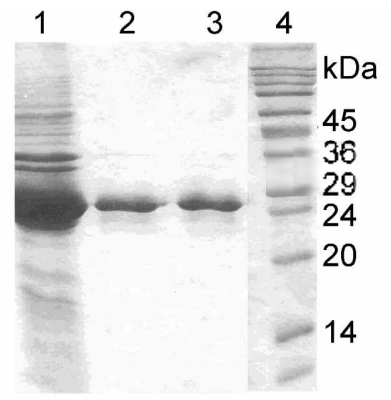

(c)

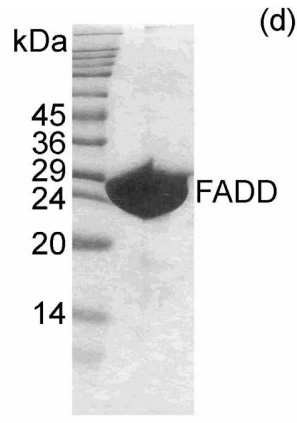

(d)

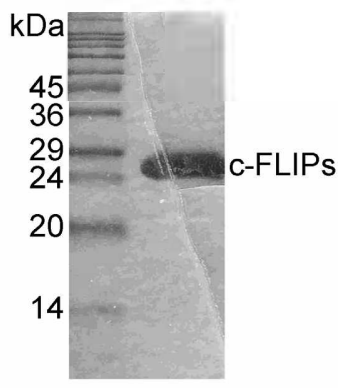

(e)

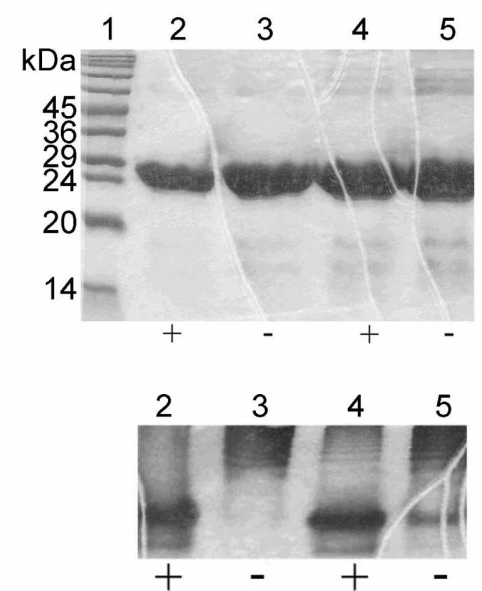

(f)

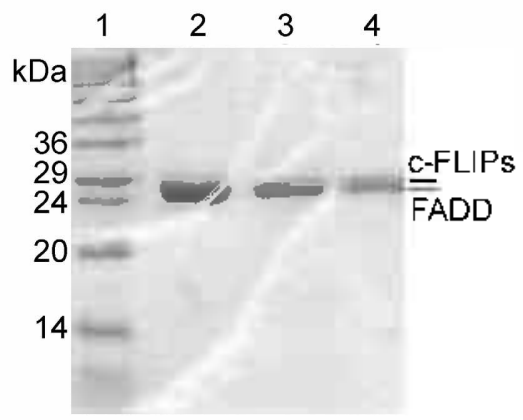

Figure 1. SDS-PAGE: and native gels of purified FADD and e-FLIPS proteins. (a) Fractions of FADD expressed in E. coll BL2l(DF:3). Lane 1: supernatant of 'lysed hacteria after induction by IPTG; Lanes 2 and 3: supernatants after resuspension of ammonium sultate precipitate; Lane 4: molecular weight markers (b) Fractions of c-FLII's expressed in E. coli BL21(DE:3). Lane 1: supernatant of lysed bacteria afier induction; I anes 2 and 3 : supematants alter resuspension; I anc 4 : molecular weight markers (c) Final concentraled fRDI) protein (26 kI)a). (d) Final concentrated e-FLIPS prokin (28 kDa). (e) Comparison of SDS-PAGE (top) and native (bottom) gels after using a superdex 75 columm; Lanes 2 and 4: purified FADD; Lanes 3 and 5: inactive proteins. (+): homogenteous protsin; (-): non-homogeneous protein and the aggregates of higher mass. (1) Binding of FADD and c-FLIPS complex shown in SDS-PACF analysis from the size-exclusion column binding $I$ anes 2-4: dilferent volumes $(5,3$ and 2 ul) of FADI) (bottom) and c-FI.IPS (top) complex. 

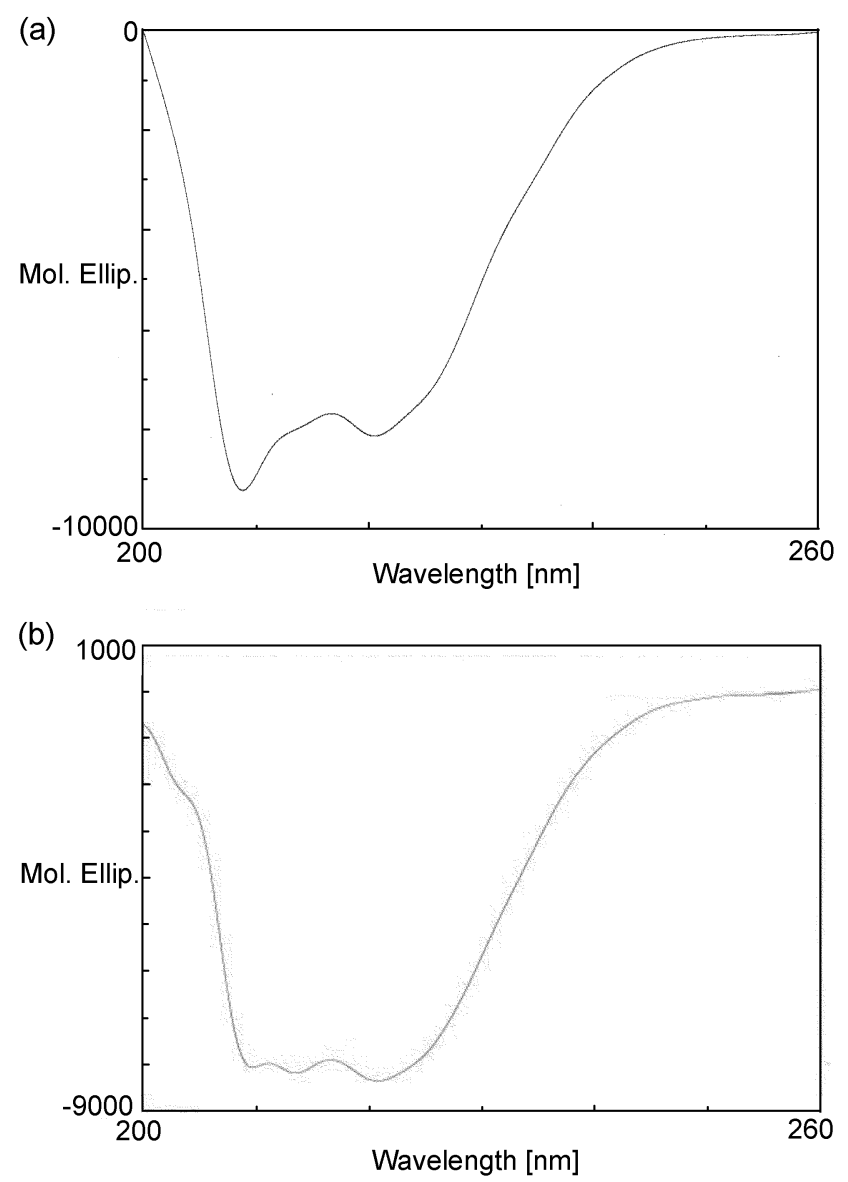

Figure 2. Far-UV CD spectra of $F A D D$ and $c-F L I P S$. CD spectra were measured from 200 to $260 \mathrm{~nm}$ using a $0.1 \mathrm{~cm}$ pathlength cell, and the CD signals were merged using the CDNN. (a) FADD; (b) c-FLIP. Spectra were typically recorded as an average of three scans at $25^{\circ} \mathrm{C}$.

cxhibited three negative maxima at 208,214 , and $222 \mathrm{~nm}$ (Figs, $2 \mathrm{a}$ and $\mathrm{b}$ ). FADD protein is composed mostly of alpha-helical structure and c-FLIP's protein is presumed to super-secondary structure, which is motifs consisting of no more than three secondary structure elements. The dynamic light-scattering spectra of the FALD) (Rh [nm] $=5.681, \mathrm{Cp}$ $[\mathrm{nm}]=2.532$ and $\mathrm{Cp} / \mathrm{Rh}[\%]=44.4)$ and $\mathrm{c}-\mathrm{FLIP}_{\mathrm{s}}(\mathrm{Rh}[\mathrm{nm}]=$ $5.250, \mathrm{Cp}[\mathrm{mm}]=1.710$ and $\mathrm{Cp} / \mathrm{Rh}[\%]=32.3$ ) were obtained to identify the distributions of species of differing molecular masses, the degree of aggregation, shape, and branching (SEC-mode). Dynamic light-scattering spectra were recorded with 0.1-0.2 uM protein samples. The proteins were purified to homogeneity as shown in the regularization process, and an aggregation peak was not found (Figs. 3 a and $b$ ).

The extrinsic pathway is initiated by ligation of transmembrane death receptors (CD95, the TNF receptor, and the TRAIL receptor) to active membrane-proximal (activator) caspases (caspase- 8 and -10 ), which in turn cleave and activate effector caspases such as caspase- 3 and -7 . This pathway can be regulated by c-FLIP, which inhibits upstream activator caspases, and inhibitors of apoptosis proteins (IAPs), which affect both activator and effector
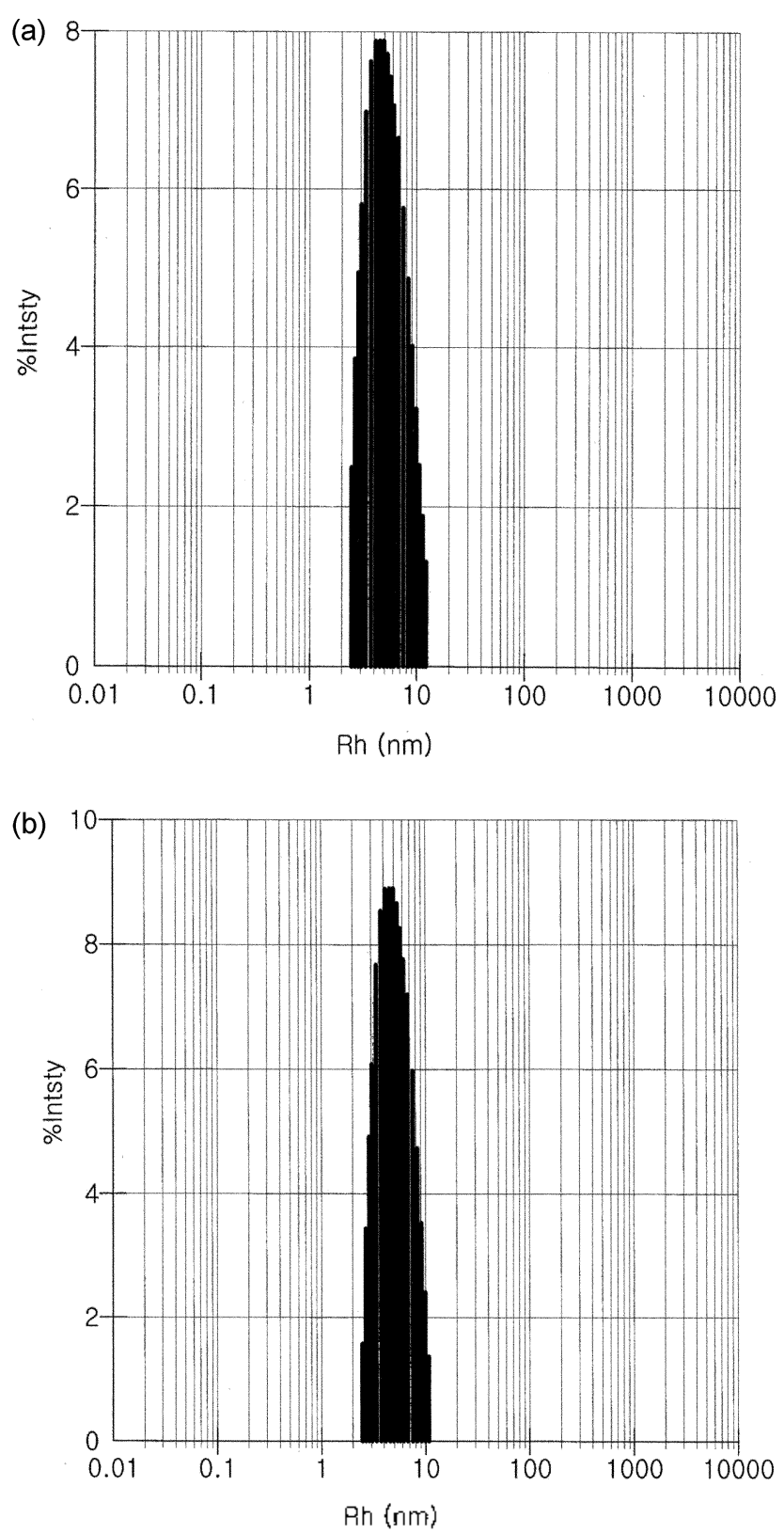

Figure 3. Light-scattering spectra of the FADD (a) and c-FLIPs $(b)$ The light-scattering spectra were recorded with $0.1-0.2 \mathrm{uM}$ protein samples. The regularization histograms (the sharp peak in the middle) are shown as the homogeneity of purified $F \wedge D D$ and $c-$ FLIPs proteins in solution.

caspases. To investigate the interaction between the FADD protein and c-FLIPs, the binding affinity of FADD for the c-FLIPs was estimated by surface plasmon resonance spectroscopy (BIAcore) (Fig, 4). Sensograms of FADD binding to cFLIPs were used to calculate the kinetic binding constants. Background sensorgrams were then subtracted from the experimental sensorgrams to yield representative specific binding. The kinetic parameters of the binding of FADD to e-FLIP are shown in Table 1. It was measured twice to observe the reproduction of the experiment at different concentrations. We found that FADD indeed binds c-FLIPs strongly with an apparent $K_{0}$ of $178 \mathrm{nM}$ for the $1^{\text {st }}$ experi- 


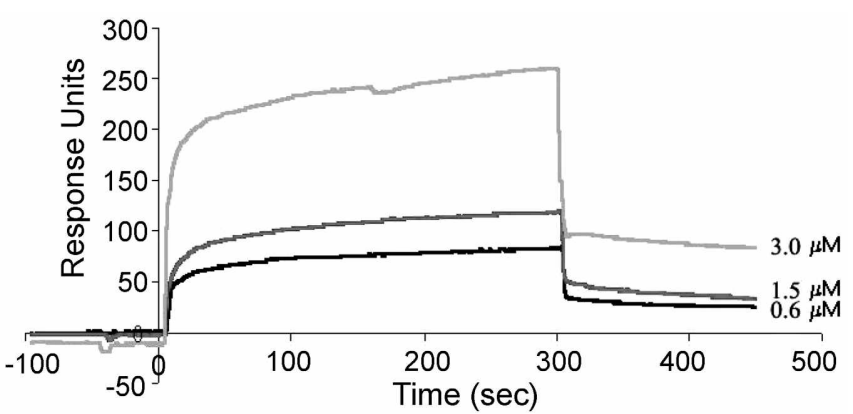

Figure 4. BIAcore biosensor analysis of binding of FADD to $\mathrm{c}-$ FLIPs a 25 "C. The sensorgrams for $0.6,1.5$, and 3.0 uM human $\mathrm{c}$ FLIPs are shown. which were used to calculate the dissociation constants. The FADD was immobilized to the dextran matrix, and c-FLIPS sanples at the three indicaled concentrations were injueted for $5 \mathrm{~min}$. The kinetic parameters of the binding reactions were determined using the l3 hevaluation version 2.1 soltware provided by the manulacturer. $A$ conlrol experiment using $3 S A$ did not show a delectable binding response to either of the enrymes.

Table 1. Kinetic parameters of binding of FADD to c-FLII's"

\begin{tabular}{|c|c|c|c|c|}
\hline $\begin{array}{l}\text { Vumbers of } \\
\text { experiment }\end{array}$ & $\begin{array}{c}\text { Concs of } \\
\text { analyte (nM) }\end{array}$ & $k_{1: 1}\left(\mathrm{M}^{-1} \mathrm{~s}^{-1}\right)$ & $k_{i l}\left(\mathrm{~s}^{-1}\right)$ & $k_{1}(\mathrm{M})$ \\
\hline \multirow[t]{3}{*}{$1^{s 1}$} & 600 & $9.57 \times 10^{3}$ & $9.97 \times 10^{11}$ & $1.04 \times 10^{7}$ \\
\hline & 1500 & $4.76 \times 10^{3}$ & $8.24 \times 10^{-1}$ & $1.73 \times 10^{-7}$ \\
\hline & 3000 & $3.62 \times 10^{3}$ & $9.25 \times 10^{11}$ & $2.56 \times 10^{7}$ \\
\hline$K_{1}(\mathrm{nM})$ & & & & 178 \\
\hline \multirow[t]{4}{*}{$2^{\text {nd }}$} & 1000 & $4.38 \times 10^{3}$ & $6.22 \times 10^{-1}$ & $1.42 \times 10^{-7}$ \\
\hline & 2500 & $2.75 \times 10^{3}$ & $8.22 \times 10^{-1}$ & $2.98 \times 10^{-7}$ \\
\hline & 5000 & $5.19 \times 10^{3}$ & $6.96 \times 10^{1}$ & $1.34 \times 10^{7}$ \\
\hline & $5000^{h}$ & $4.35 \times 10^{3}$ & $6.96 \times 10^{-1}$ & $1.60 \times 10^{-7}$ \\
\hline$K_{1},(\mathrm{nM})$ & & & & 191 \\
\hline
\end{tabular}

"The association rate constant $\left(k_{i}\right)$ was determined fom a plot of In $[\Lambda$ bs $(\mathrm{d} R \mathrm{~d} \mathrm{~d} t)$ versus time, where $R$ is the intensity of the surface plasmon resonance signal at linc $t$. The dissociation rate constant $\left(k_{d}\right)$ was determined from a plot of In $\left(R_{t} / R\right)$ versas lime, where $R_{0}$ is the resonance signal intensity' at time $/$ rero. 'The apparent $K_{\Gamma}^{\prime}$ was calculated from the kinctic constants $K_{1}(\mathrm{M})=k_{1} / k_{\mathrm{x}}$. "In a repeat of the experiment, the value was showth in the same concentration.

ment and $191 \mathrm{nM}$ for the $2^{\text {nd }}$ experiment. As compared with both of the experimental results, the average dissociation value of the $1^{\text {st }}$ experiment is very similar to that of the $2^{\text {nd }}$, and the association rate constant $\left(k_{\mathrm{a}}\right)$ between FADD and cFL.IPS is gradually decreased at high analyte concentrations in the range between 3,000 and $5,000 \mathrm{nM}$. This might cause the reproduction of aggregation according to the high analyte concentration, as well as a different $\mathrm{pH} T$ according to the bufler change in solution. From the binding of FADD and $\mathrm{c}-$ FLIPS, we presume that $\mathrm{c}$-FLIPs has the characteristics of an inhibitory of apoptosis and that it blocks caspase- 8 activation. No association between c-FLIP and caspase-8 or FADD could be detected without receptor triggering. ${ }^{37}$ This demonstrates that no stable preformed complex between FADD, caspase-8, and c-FLIP exists in cytoplasm in vivo. There are conllicting reports about whether c-FLIP interacts with ГАГГГ) and/or caspase- 8 . In this study, we found direct interaction of $\mathrm{FADD}$ with c-FLIPS withoul receptor trig- gering, and estimated the actual binding a finity between the two proteins by employing surface plasmon resonance spectroscopy (Fig. 4). Also, in order to conlirm the interaction between FADT) and c-FLIP, FADD protein was mixed with c-FLIPs protein in size-exclusion column at 4 " $\mathrm{C}$ for 12 hrs. The mixed protein solution was loaded to a gel filtration column, and the FADD-C-FL.JPS complex revealed itself in an SDS-PAGE, analysis (Fig. 10 ).

The fluoresence emission spectra of the purified F $\triangle D D$ and c-FLIPs proteins were checked, and $\hat{\lambda}_{\max }$ curve was found at $301 \mathrm{~nm}$ or $305 \mathrm{~nm}$, respectively, suggesting a similarity in conformation of the FADD and c-FLIPs proteins. The spectra of the FADID and c-FLIPS prokins represented the unusual emission of a tryptophan with $\lambda_{\max }$ at 301 $\mathrm{nm}$ or $305 \mathrm{~mm}$, consistent with the solvent-inaccessible environment of the tryptophan residue. The fluoresecnec intensity of the FADD was somewhat increased by the exposed tryptophan residues, suggesting that the tryptophan lluorescence of the FADD mainly originates from aromatic anino acids. FADD has C-terminal DD and N-terminal DED. A signal of Fas-mediated apoptosis is transferred though an adaptor protein, FADD. $\wedge$ death effector domain of FADD has three tryptephan residues (Trpl12, Trp 148 , and $\operatorname{Trp} 198$ ), whereas those of e-FLIPs have no tryptophan residues. The death domain of the FADI) has no tryptophan residues. The FADD DFD has two hydrophobic palches for binding to c-FLIPs and for apoptotic activity. One of these patches contains a conserved set of hydrophobic residues that is important for its apoptotic activity and binding to the DEDs of procaspase-8. ${ }^{1 \mathrm{x}-20}$ The FADD appears to undergo some degree of temperature-dependent conformational change, because the fluoreseenee spectrum of the protein exhibits an appreciable change as a Junction of temperature, as shown in Figure 5. The fluoreseenec intensity of the FADD is about 630 a.u. at $25^{\circ} \mathrm{C}$, but at $4^{\circ} \mathrm{C}$ it is 550 a.u. This is in contrast $10 \mathrm{c}-\mathrm{FLIPS}$, which displays a smaller spectral difference. At $25^{\circ} \mathrm{C}$, an increase in the fluorescence intensity took place when the FADD and c-FLIPS were mixed together in $1: 1$ molar ratio, both at 5 uM (Fig. 5 a). These results show that the structural stability and activity of the FADD-c-FLIPss complex at $25^{\circ} \mathrm{C}$ were increased. Ilowever, no appreciable fluorescence change was detected at 4 " $\mathrm{C}$ under the same experimental conditions, which is consistent with the result fron the BIAcore biosensor analysis in a prolonged incubation (Figs. 4 and 5 b). The simple combination of the spectra of the FADD and c-FLIPs are not identical to the spectrum of the FADID-C-FLPPs complex. Probably, the tight interaction of the two proteins is accompanied by more significant conformational changes of one or both of the two proteins, which is likely to be greatly lacilitated at room temperature, because the residues of aromatic groujs are buried in the three-dimensional structure of protein and the spectrum of the $\Gamma \Lambda \Gamma \Gamma$ )-C-FLJPS complex is much more decreased than in the simple combination. Also, the less rigid and hydrophobic environment needed by the conformational change of F $A D D-c-F L . I P_{S}$ can be caused by the decreasing of fluoreseent intensity. 
(a)

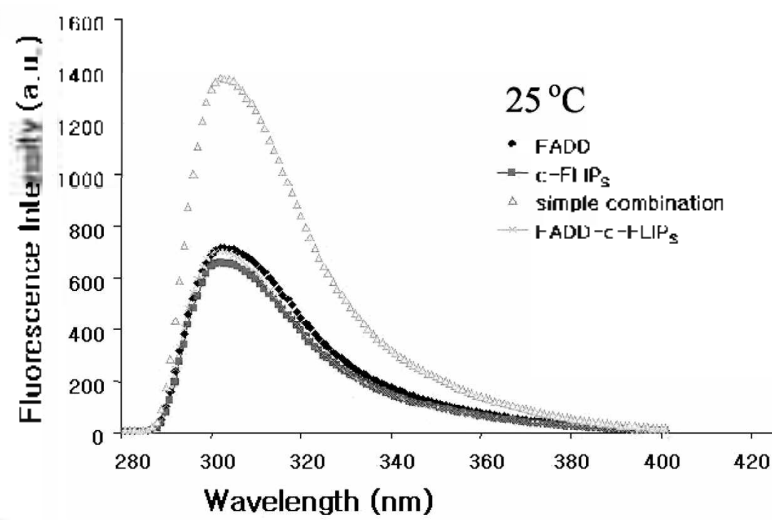

(b)

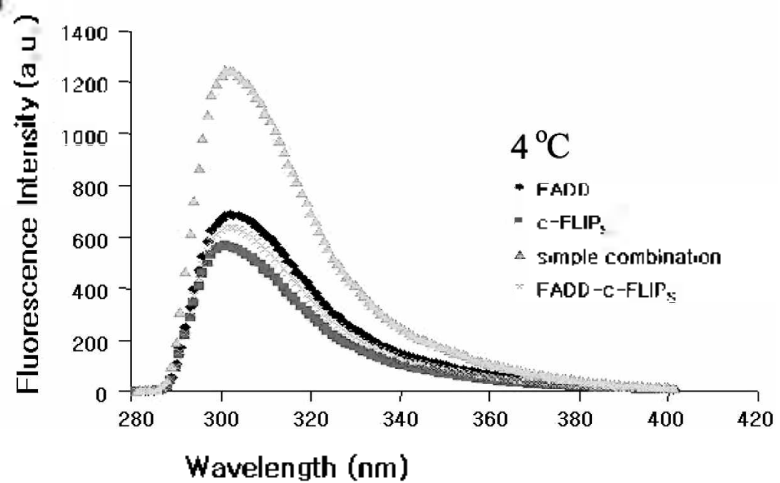

Figure 5. Temperature effect on the binding of FADI) $10 \mathrm{c}-\mathrm{FI}$.IPs Fluorescence specta of the I : I mixture of FADD and $c-F L I P$ s and the sum of the spectra of individual $F A D D$ and $c-F L I P$ s. The FADD and $c-F L I P$ ' were preinculated together for 25 min at $25^{\circ}$ "C. (a) and 4 " $\mathrm{C}$ (b), respectively. The Huoresesence specta were recorded with a wavelength of 295 nom to sxcite tryptophan and tyrosine. The concentration of each of the 1 wo proteins was $5 \mathrm{uM}$. The sample bullee contained $50 \mathrm{mM}$ Tris-HCl [pH 7.5]. $200 \mathrm{mM}$ VaCl, and $1 \mathrm{mM}$ DTT.

The majority of protein-protein interactions that thus lar identified in death receptor signaling have been through the use of isolated domains involving homotypic interaction between death domains or death effector domains. ${ }^{21}$ For example, the DD of FADD has been shown to interact with the DDD of Fas or of TRAIL receptors. The DFD domain of FADD interacts with the DFD domain of caspase-8. Ilowever, in a screen for FADD mutants that are delicient in interaction with the DDD of Fas, the majority of the identilied mutations were within the DED domain of FADD, which indicates that interactions other than homotypic associations are also involved in mediating signals from death receptors. ${ }^{22.23}$

In the present study, we show the purification and characterization of the full-length FADD and c-FLIPs proteins in $E$. coli. Also, we confirm that FADD interacts with c-FLJPs in vitro by a series of biochemical and biophysical measurements. These results indicate that c-FLIPS potently blocks FADD-mediated cell death by interlering with caspase- 8 activation.
Acknowledgements. This work was supported by Basic Research Program of the Korea Science and Engineering Foundation Grant (R03-2002-000-00007-0) and Korea Rescarch Foundation Grant (KRF-2003-042-F:00005). The authors acknowledge the beamline $6 \mathrm{~B}$ at Pohang Accelerator Laboratory, Pohang, Korea.

\section{References}

I. Krammex, P. 11. Notme 2000, 407, 789-795.

2. Schulze-Osthoff, K.: Ferrari. D.: I.os, M.: Wessclborg. S.: Poter, M. Г. Eut J. Biochem. 1998, 254, 439-459.

3. Kischkel, Г, C.; I tollbardt, S.; Behrmann, L,: Gimer, M.: Pawlita, M.: Krammer, P. IL; Puter, М. Г. EMBO J. 1995, /4, 55795588.

4. Medema, I. P.; Scaffidi, C.; Kischkel, F. C... Shevchenko, A.; Mantn, M.; Krammer, P. H.: Petex; M. [.. EMABO J. 1997, 16, 2794 2804 .

5. Abe, K.; Kurakin, A.: Mohseni-Maybodi, M,; Kay, B.; Khosravilas, R. Atw SY Acal Sci. 2000, $926,52-63$.

6. Mariani, S. M.; Krammer, P. 11. Eut f. Hommot. 1998, 28, 14921498.

7. Pitti, R. M.; Marsters, S. A.; Ruppert, S.; Donahuc, C. I.: Moore, A.; Ashkcnazi. A.J. Biol. Chem. 1996, 27/, 12687-12690.

8. Wilcy, S, R,; Schooley, K.; Smolak, P. J; [Din, W. S.; Iluang, C. P: Nicholl, J. K.; Sutherland, G. R.; Smith, T. D.: Rauch, C.; Smith, C. A. Immunity 19y5, 3, 673-682.

9. Thome, M.; Schncider, P.; I lolmann, K.: lickenscher; H.; Meirl, l:.; Neipel, F.: Mattmann, C.: Burns, K.: Bodmer, I. L.: Schrotes: M.; Scaftidi, C.; Krammer, P. H.:; Peter, V. Г.: Tschopp, J. Natwe 1997, $386,517-521$

10. IIu, S.: Vincenz, C.; Buller, M.; Dixit, V. M. J. Biol. Chem. 1997, $272.9621-9624$.

11. Ifmler, M.; Thome, M.; I lahne, M.; Schneider, P.; ILofmann, K. Stciner, V.: Bodtuct, J. 1.:; Schroter, M.; Burns, K.: Mattmants, C., Rimoldi, D:; French. I., Г.: Tschopp, J. Wottle 1997, 38\%, 190 195.

12. Goltser, Y, V; Kovalenko, $\Lambda$, V; Amold. E.; Varfolomeev, E., Г., Bfodianskii, V. M.; Wallach, D. I. Biol. Chem. 1997, 272, 1964119644

13. I[u, S.; Vincenz, C.: Buller, M.; Dixit, V. M. J. Biol. Chem. 1997, $272,17255-17257$

14. Shu, II, B.; I Ialpir, D, R, Coaddel, D, V, Immunin 1997, 6, 75I763.

15. Srinivasula, S. M.: Ahmad, M.; Onilic, S.; Bullich, F.: Banks, S.; Wang, Y.; Fernandes-Alnemri, T.; Croce, C.. M.; Litwack, G; Tomaselli, K. J.: Amstrong. R. C.; Anemri, E. S. J. Biol. Chem. $1997,272,18542-18545$.

16. Inohara, N.; Koscki, T.: IIu, Y, Chen, S.; Nuncz, Gi Proc. Nohl Acat. Sci. U.S.A. 1997, 94, 10717-10722.

17. Seaffïdi, (..: Schmit7, I.: Krammes, P. I1.; Peter, M. I. .f. Biol. Chem. 1999, 274, 1541-1548.

18. Ciberstadt, M.: IItang, B.: Chen, 7..; Mcadows, R. P.: Ng. S.-C.; 7.hang, I , I enardo, M. Ji Fesik, S. W. Wathe 1998, 392, 941945.

19. I. a, [), T,; ('hoi, J. [), Bull. Korew Chem. Soc. 2005, 6, 916120.

20. Kim, K. S.; Kang, I. II. Bult. Korean Chem. Soc. 2005, 8, $1255-$ 1259.

21. Fosik, S. W. Cell 2000, /03, 273-282.

22. Thotburn, A. Cell Signal 2004, /6, 139-144.

23. Thomas, I. R.; Stilman, D. J.; Thorbum, A. J. Biol. Chem. 2002, $277,34343-34348$. 